\title{
Respon Petani Padi Terhadap Program Billing System Pupuk Bersubsidi di Kecamatan Candipuro Kabupaten Lampung Selatan
}

\section{The Responses of Rice Farmers to the Billing system Program for Subsidized Fertilizer in Candipuro Sub-District, South Lampung Regency}

\author{
Oleh: \\ Rahmalina $^{1^{*},}$, Dewangga Nikmatullah ${ }^{2,}$ dan Serly Silviyanti ${ }^{2}$ \\ ${ }^{1}$ Dinas Ketahanan Pangan, Tanaman Pangan dan Hortikultura Provinsi Lampung \\ Jl. ZA. Pagar Alam No. 1 Bandar Lampung, Lampung, Indonesia \\ ${ }^{2}$ Program Studi Magister Penyuluuhan dan Komunikasi Pertanian, Fakultas Pertanian, Universitas Lampung. \\ Jl. Sumantri Brojonegoro 1, Bandar Lampung, 35145, Lampung, Indonesia \\ *E-mail: uncuqoe@gmail.com
}

Received June 01, 2020; Revised June 21, 2020; Accepted June 26, 2020

\begin{abstract}
ABSTRAK
Salah satu program pemerintah untuk meminimalisir distribusi pupuk bersubsidi yang tidak tepat waktu dan tidak tepat sasaran program billing system.. Penelitian ini bertujuan untuk mengetahui faktor-faktor yang berhubungan dengan respon petani padi pada program billing system. Penelitian dilakukan di Kecamatan Candipuro, Kabupaten Lampung Selatan. Pengambilan sampel menggunakan teknik purposive sampling, yaitu petani peserta program billing system yang berjumlah 93 orang. Jenis data yang digunakan dalam penelitian ini adalah data primer dan sekunder. Waktu pengambilan data penelitian dilaksanakan pada bulan Oktober 2019. Pengujian hipotesis dilakukan dengan menggunakan analisis peringkat korelasi rank Spearman. Hasil penelitian menunjukkan bahwa respon petani terhadap program billing system dilihat dari manfaat, pelaksanaan dan aksesibilitas program masuk dalam kategori baik. Faktor-faktor yang berhubungan secara signifikan dengan respon petani terhadap program billing system adalah tingkat pengetahuan, tingkat pemenuhan syarat program, dukungan pemerintah dan kepemilikan modal petani untuk menebus pupuk subsidi.
\end{abstract}

Kata kunci: billing system, pupuk subsidi, respon petani,

\section{ABSTRACT}

One of the government programs that become a means to minimize the distribution of subsidized fertilizer that is not timely and on target is to create a Billing system Program policy. This study aims to determine the factors associated with the response of rice farmers in the billing system program. The study was conducted in Candipuro District, South Lampung Regency. Sampling using a purposive sampling technique, that was farmers from the participants of the program, amounting to 93 people. The type of data in this study is primary and secondary data. The time of research data collection was carried out in October 2019. Hypothesis testing was performed using the Spearman Rank correlation analysis. The results showed that the response of farmers to the Billing system Program is in a good category. It was viewed from the benefits, implementation, and the program acsessibility program. Factors that are significantly related to farmers' responses to the program are the level of knowledge, the required fullfilment level, government support, and farmers' capital ownership to make up for subsidized fertilizer. 


\section{PENDAHULUAN}

Pangan merupakan kebutuhan mendasar bagi manusia untuk dapat mempertahankan hidup karena itu kecukupan pangan bagi setiap orang setiap waktu merupakan hak azasi yang layak untuk dipenuhi. Berdasarkan kenyataan tersebut, masalah pemenuhan kebutuhan pangan bagi seluruh penduduk setiap saat di suatu wilayah menjadi sasaran utama kebijakan pangan suatu negara. Indonesia sebagai negara dengan jumlah penduduk yang besar menghadapi tantangan yang sangat kompleks dalam memenuhi kebutuhan pangan penduduknya, sehingga masalah ketahanan pangan menjadi isu sentral dalam pembangunan dan menjadi fokus dalam pembangunan pertanian (Ditjen Prasarana dan Sarana Pertanian, 2018).

Seiring bertambahnya jumlah penduduk, bertambah pula kebutuhan pangan yang harus disediakan. Oleh karena itu, pencapaian produksi pertanian yang terus dibarengi dengan alih fungsi lahan pertanian menjadi tantangan bagi pemerintah khususnya Kementerian Pertanian Republik Indonesia dalam peningkatan produksi pertanian. Selain itu lahan, infrastruktur termasuk irigasi, lingkungan (iklim), permodalan petani, ketersediaan, serta keterjangkauan sarana produksi khususnya pupuk merupakan faktor utama yang berpengaruh dalam peningkatan produksi pertanian (Hadi et al, 2007).

Pupuk merupakan salah satu sarana produksi yang sangat menentukan produksi dan produktivitas pertanian. Oleh karena itu, ketersediaan pupuk di pasar baik dari segi kuantitas, kualitas dan harga yang terjangkau menjadi salah satu syarat yang harus dapat dijamin oleh pemerintah. Peningkatan produksi khususnya tanaman padi di Provinsi Lampung.

Produksi pada di Provinsi Lampung meningkat pada tahun 2017 dan 2018. Pada tahun 2017 produksi padi di Provinsi Lampung sebesar 4.248.977 ton dan meningkat menjadi 4.343 .586 ton pada tahun 2018. Kabupaten sentra padi di Provinsi Lampung terletak di Kabupaten Lampung Tengah, Lampung Timur, Lampung Selatan dan Tulang Bawang. Kabupaten Lampung Tengah merupakan wilayah dengan produksi padi tertinggi di Provinsi Lampung. Pada tahun 2018 produksi padi Kabupaten Lampung Tengah sebesar 771.669 ton. Data produksi padai di Provinsi Lampung bedasarkan wilayah (kabupaten) ditampilkan pada Tabel 1.

Tabel 1.

Produksi padi di Provinsi Lampung tahun 2017-2018

\begin{tabular}{llrr}
\hline \multirow{2}{*}{ No. } & \multirow{2}{*}{ Kabupaten/Kota } & \multicolumn{2}{c}{ Produksi (Ton) } \\
\cline { 3 - 4 } & & 2017 & \multicolumn{1}{c}{2018} \\
\hline 1. & Lampung Barat & 147.606 & 170.051 \\
2. & Tanggamus & 362.873 & 344.235 \\
3. & Lampung Selatan & 600.393 & 486.920 \\
4. & Lampung Timur & 667.730 & 660.345 \\
5. & Lampung Tengah & 775.926 & 771.669 \\
6. & Lampung Utara & 250.895 & 248.834 \\
7. & Way Kanan & 231.571 & 260.137 \\
8. & Tulang Bawang & 329.439 & 386.479 \\
9. & Pesawaran & 215.953 & 233.091 \\
10. & Pringsewu & 138.009 & 138.421 \\
11. & Mesuji & 277.215 & 387.614 \\
12. & Tulang Bawang & 113.636 & 118.344 \\
& Barat & & \\
13. & Pesisir Barat & 101.696 & 102.469 \\
14. & Bandar Lampung & 10.190 & 9.512 \\
15. & Metro & 25.899 & 25.465 \\
\hline Jumlah & 4.248 .977 & 4.343 .586 \\
\hline Sumber: Badan Pusat Statistik
\end{tabular}

Sumber: Badan Pusat Statistik, 2017

Penggunaan pupuk pada kegiatan intensifikasi berhubungan dengan penggunaan bibit unggul yang perlu diimbangi dengan asupan hara yang cukup, sedangkan upaya ekstensifikasi pupuk diperlukan untuk peningkatan produktivitas lahan dan untuk mengembalikan produktivitas lahan dan untuk mengembalikan produktivitas tanah lahan konversi (Sukana dan Notohadiprawiro, 2006). Efektivitas penggunaan pupuk diarahkan pada penerapan pemupukan berimbang dan organik sesuai rekomendasi spesifik lokasi atau standar teknis penggunaan pupuk yang dianjurkan (Ditjen Prasarana dan Sarana Pertanian, 2018).

Provinsi Lampung merupakan salah satu provinsi sentra produksi padi di Indonesia. Produksi padi Provinsi Lampung 
pada tahun 2016 menurut Badan Pusat Statistik (BPS, 2016) yakni 4,02 juta ton dan naik menjadi 4,32 juta pada tahun 2017. Capaian itu membuat Lampung sebagai provinsi ketujuh produsen padi nasional dengan kontribusi 5,33 persen.

Untuk mempertahankan peringkat tersebut, salah satu faktor yang perlu diperhatikan adalah penyediaan pupuk bersubsidi sesuai dengan kriteria 6 (enam) tepat yaitu: jumlah, jenis, harga, tempat, waktu, dan mutu sesuai dengan Peraturan Gubernur Lampung Nomor 99 Tahun 2016. Pemerintah Provinsi Lampung melakukan koordinasi teknis dengan Tim Pokja Pupuk Nasional jajaran Kementerian Perekonomian, Kementerian Pertanian, Kementerian Keuangan, Kementerian Perindustrian, Kementerian Perdagangan, PT. Pupuk Indonesia, PT. Pusri Palembang, dan PT. Petrokimia Gresik. Atas peran aktif dan dukungan dari seluruh pihak maka terwujudlah pelaksanaan pola billing system penyaluran pupuk bersubsidi di Provinsi Lampung.

Hasil dari koordinasi tersebut dituangkan dalam Peraturan Gubernur Lampung Nomor 32 Tahun 2015 sebagai dasar pelaksanaan pola distribusi penebusan pupuk bersubsidi secara billing system. Aplikasi ini merupakan suatu inovasi terbaru dari Pemerintah Daerah (pemda) Provinsi Lampung sebagai bentuk keseriusan Gubernur Lampung dalam menanggapi permasalahan pendistribusian pupuk bersubsidi ke petani dan untuk mendukung peningkatan produksi padi di Provinsi Lampung.

Dasar pemikiran program inovasi billing system adalah merujuk pada berbagai hal antara lain: (1) permasalahan penyediaan dan distribusi pupuk bersubsidi yang selalu terjadi setiap tahun/musim tanam, (2) menurunnya kepercayaan petani terhadap manfaat pupuk bersubsidi yang realisasinya jauh dari prinsip 6 (enam) tepat: jenis, jumlah, harga, tempat, waktu, dan mutu, (3) database rencana definitif kebutuhan kelompok (RDKK) pupuk bersubsidi belum menjadi acuan bersama dalam distribusi pupuk sampai ke kelompok tani, (4) pupuk bersubsidi adalah barang dalam pengawasan, bukan barang yang diperdagangkan, (5) sebagai upaya pemberdayaan kelembagaan di tingkat desa dalam penyaluran/distribusi pupuk bersubsidi sehingga perlu diberikan kemudahan dan tanggungjawab untuk kesejahteraan bersama, (6) dalam penyaluran pupuk bersubsidi sampai dengan kelompok tani, diperlukan prosedur yang lebih sederhana, transparan dan terpadu secara online (berbasis IT), dan (7) peluang penambahan subsidi kepada petani melalui pengembangan system pembayaran secara online (billing system) yang terintegrasi.

Penebusan pupuk besubsidi dengan menggunakan fasilitas e-billing yang didukung penuh oleh Bank Lampung, merupakan salah satu upaya pemerintah dalam upaya memperbaiki tataniaga pupuk bersubsidi. Selain dari berbagai manfaat yang diharapkan di atas, dengan adanya billing system juga diharapkan akan ada peningkatan fungsi kelembagaan petani dalam berorganisasi, serta ada penurunan tingkat penyelewengan penyaluran pupuk bersubsidi. Konsekuensi dari sistem ini adalah dibutuhkan pengawalan yang lebih erat dalam awal penerapan e-billing penyaluran pupuk bersubsidi, terutama kesiapan operasional penggunaan smartphone atau laptop sebagai sarana pemesanan secara online, kesiapan modal/dana untuk penebusan pupuk bersubsidi, dan kesiapan petani dalam mengadopsi dan melaksanakan suatu inovasi baru di bidang pertanian (Listiana et al. 2020). Pola billing system diharapkan dapat membantu petani agar lebih terjamin untuk memperoleh pupuk bersubsidi sesuai kuotanya, dapat menjaga kestabilan harga eceran tertinggi (HET) dan memberikan kemudahan bagi perusahaan pupuk untuk berkoordinasi dengan pemerintah. Selain itu, pola ini memberikan dampak yang sangat positif terutama dalam hal pemenuhan pencapaian tujuan 6 (enam) tepat, yaitu tepat waktu, jumlah, jenis, mutu, tempat, dan harga. 
Efektivitas kegiatan penyuluhan dalam mensosialisasikan program billing system akan membawa dampak terhadap perubahan perilaku petani dalam memenuhi kebutuhan sarana produksinya yaitu pupuk yang tepat waktu dan tempat. Apabila kebutuhan pupuk petani tidak tersedia sesuai dengan kebutuhan maka kondisi ini akan terus berlanjut sampai dengan musim tanam selanjutnya, bila tidak ada solusi yang tepat. Program billing system pupuk bersubsidi hadir sebagai sebuah inovasi guna menjadi solusi pemecahan masalah pupuk bersubsidi di Provinsi Lampung, tetapi apakah sebagai suatu inovasi baru, petani memiliki ketetarikan yang tinggi dalam penerapan $e$ billing pupuk bersubsidi di lapangan. Secara psikologi, perubahan perilaku petani didasarkan atas kebutuhan.

Menurut teori Maslow (Pudji dan Sriningsih, 2003), kebutuhan (needs) yang ada pada manusia akan menimbulkan keinginan (wants), dan dari keinginan itu kemudian muncul motivasi (motivation) untuk memenuhi kebutuhan itu, sehingga muncullah harapan (expectation). Selanjutnya menurut Azwar dalam Pudji dan Sriningsih (2003), kondisi intern yaitu komponen kognitif, afektif, dan konotif akan berinteraksi secara selaras dan konsisten membentuk pola sikap (attitude) tertentu terhadap objek psikologis yang dihadapinya, dan sikap yang terbentuk merupakan predisposisi perilaku. Sejalan dengan itu bentuk respon petani terhadap program billing system yang diamati dalam penelitian ini merupakan sikap petani dalam penerapan aplikasi ini untuk memenuhi kebutuhan pupuk mereka. Berdasarkan halhal tersebutlah, penulis memiliki ketertarikan untuk dapat meneliti respon kelompok tani terhadap program billing system pupuk bersubsidi di Kecamatan Candipuro, Kabupaten Lampung Selatan.

\section{METODE PENELITIAN}

Penelitian ini dilakukan di Kecamatan Candipuro, Kabupaten Lampung Selatan. Pemilihan lokasi penelitian ini dilakukan secara sengaja (purposive) dengan pertimbangan bahwa Kecamatan Candipuro merupakan salah satu kecamatan yang memiliki jumlah kelompok tani dengan jumlah yang cukup banyak yang telah mengaplikasikan program billing system pupuk bersubsidi selama tahun 2016-2019 dan sebagai kecamatan pertama tempat peluncuran aplikasi ini. Waktu pengambilan data dilaksanakan pada Bulan Oktober 2019.

Responden penelitian adalah petani yang tergabung dalam kelompok tani (poktan) yang telah menyusun RDKK dan melakukan penebusan pupuk bersubsidi melalui program billing system di Kecamatan Candipuro Kabupaten Lampung Selatan yang menerapkan program billing system pupuk subsidi sebanyak 93 petani. Jenis data yang digunakan dalam penelitian ini yaitu data primer dan sekunder. Analisis data pada penelitian ini menggunakan uji korelasi rank Spearman yang biasa disebut korelasi berjenjang $\left(\mathrm{r}_{\mathrm{s}}\right)$ yang berguna untuk mengukur tingkat hubungan antara dua variabel atau variabel bebas dengan variabel terikat yang berskala ordinal (Riduwan, 2010).

\section{HASIL DAN PEMBAHASAN}

\section{Keadaan Umum Responden}

Karakteristik responden pada penelitian ini dilihat dari umur, lama menjadi anggota kelompok tani, dan lama usahatani. Umur responden berkisar antara 22-72 tahun dengan rata-rata umur responden adalah 49 tahun. Hal ini menunjukkan bahwa rata-rata responden berada pada kelompok usia kerja. Pada usia kerja ini diharapkan anggota kelompok tani memiliki tingkat kemauan, semangat dan kemampuan untuk dapat melaksanakan kegiatan usahatani yang dijalaninya. Umur petani dalam penelitian ini termasuk dalam kategori umur produktif. Menurut Mantra (2004), sebaran umur petani berdasarkan umur produktif secara ekonomi dapat dibagi menjadi 3 klasifikasi, yaitu kelompok umur 0-14 tahun merupakan kelompok usia belum 
produktif secara ekonomi, kelompok umur 15-64 tahun merupakan kelompok usia produktif, dan kelompok umur diatas 65 tahun merupakan kelompok usia tidak lagi produktif.

Berdasarkan hasil penelitian, lama menjadi anggota kelompoktani berkisar antara 2-35 tahun. Responden terbanyak bergabung selama 14-24 tahun dengan persentase 45,17 persen. Petani di Kecamatan Candipuro rata-rata tergabung kedalam kelompok tani pada usia 20-30 tahun yang merupakan pada usia tersebut responden baru memulai usahatani. Keikutsertaan responden ke dalam kelompok tani didasari oleh tingkat kesadaran akan manfaat dari menjadi anggota kelompok. Selain itu hasil penelitian menunjukkan bahwa sebagian besar petani responden telah melakukan usahatani lebih dari 10 tahun (69 persen) sehingga dapat dikatakan bahwa petani di Kecamatan Candipuro Kabupaten Lampung Selatan telah lama berusatani padi. Dilihat dari lamanya bertani ini, mayoritas responden yang berkecimpung dalam pengelolaan tanaman padi sudah lama dan berpengalaman.

\section{Faktor-faktor yang berhubungan dengan respon petani}

\section{Pendidikan formal responden $\left(X_{1}\right)$}

Hasil penelitian di lapangan menunjukkan bahwa pendidikan formal responden terendah adalah SD dan pendidikan tertinggi adalah perguruan tinggi. Responden berpendidikan formal SMP - SMA sebanyak 56\%, berpendidikan SD sebanyak $35 \%$, dan $9 \%$ berpendidikan Sarjana (S1). Hal ini menunjukkan bahwa petani di Kecamatan Candipuro memperhatikan tingkat pendidikan mereka dalam rangka meningkatkan kapasitas diri. Pendidikan berperan penting bagi implementasi program, serta mempengaruhi dalam penyerapan informasi inovasi yang bermanfaat bagi peningkatan hasil produksi padi (Andriyani, 2019; \& Wahyuni, 2019).
Lama mengikuti program billing system pupuk bersubsidi $\left(X_{2}\right)$

Sebanyak $87 \%$ atau 81 responden telah mengikuti program billing system pupuk bersubsidi selama $2,1-3$ tahun, $10 \%$ atau 9 responden telah mengikuti program selama $1,1-2$ tahun, dan hanya tiga persen yang baru bergabung sistem billing system. Hal ini menunjukkan bahwa dalam mengembangkan usahatani, seorang petani yang dalam jangka waktu lebih lama berusahatani akan mengalami proses belajar yang lebih banyak sehingga akan lebih memudahkan dalam mengerjakan atau menerapkan inovasi.

\section{Luas lahan usahatani $\left(X_{3}\right)$}

Luas lahan petani di daerah penelitian yaitu berkisar 0,125 ha sampai dengan 2 ha. Hal ini sesuai dengan syarat untuk memperoleh pupuk bersubdi yaitu maksimal luas lahan usahatani yaitu seluas 2 ha. Petani dengan luasan lahan $1,375-2$ ha sebanyak $87 \%$ atau 81 orang, $0,76-1,375$ ha sebanyak $9 \%$ atau 8 orang, dan $4 \%$ memiliki lahan 0,125 - 0,75 ha. Lahan responden petani merupakan milik sendiri, rata-rata luas lahan yang dimiliki oleh petani yaitu 1,16 ha. Seluruh lahan yang dikelola oleh responden masuk dalam usulan rencana definitif kebutuhan kelompok (RDKK).

\section{Status kepemilikan lahan $\left(X_{4}\right)$}

Responden yang memiliki lahan usahatani berjumlah 82 orang atau $88 \%$, petani dengan status lahan sewa berjumlah 4 orang (4\%), dan petani dengan status lahan sakap berjumlah 7 orang (8\%). Status lahan responden milik sendiri sebagian besar berasal dari warisan orang tua.

\section{Pendidikan non formal $\left(X_{5}\right)$}

Responden mengikuti pelatihan/SL sebagai bentuk pendidikan non formal berkisar 2 10 kali pertemuan selama program billing system pupuk bersubsidi diterapkan di 
lokasi, untuk pembinaan petani mengenai program billing system, rata-rata responden hanya mengikuti 1-3 kali pertemuan. Sebanyak 35,5 persen (33 orang) responden mengikuti pelatihan dan sekolah lapang/SL mengenai program billing system ataupun mengenai program-program unggulan pemerintah lainnya sebanyak $5-7$ kali pertemuan. Sebanyak $34,4 \%$ (32 orang) responden mengikuti $2-4$ kali pertemuan, lainnya sebanyak $30,1 \%$ (28 orang) responden mengikuti $8-10$ kali pertemuan. Responden lebih banyak mengikuti pelatihan lainnya juga tidak terlepas dari masih barunya program billing system yang baru dilaksanakan 3 tahun, sedangkan sebelum adanya program ini petani telah mengikuti banyak pelatihan dan SL lainnya seperti sistem budidaya dan penanggulangan organisme pengganggu tanaman (OPT).

Tingkat pengetahuan petani terhadap program billing system $\left(X_{6}\right)$

Didalam pedoman umum pelaksanaan program billing system pupuk bersubsidi terdapat 3 (tiga) tujuan dasar pelaksanaan program billing system, yaitu (1) Menyederhanakan prosedur penebusan dan penyaluran pupuk bersubsidi, sebanyak 44 responden atau 47, $31 \%$ sangat paham/mengetahui mengenai prosedur penebusan pupuk bersubsidi melalui billing system, (2) Mengendalikan penyaluran pupuk bersubsidi, sebanyak 42 responden $(45,16 \%)$ paham/mengetahui mengenai tujuan mengendalikan penyaluran pupuk berseubsidi, dan sebanyak 54 responden $(58,06 \%)$ sangat paham/mengetahui mengenai tujuan ke tiga yaitu menjamin ketersediaan pupuk dan penerapan pupuk berimbang.

Tingkat kesulitan persyaratan program billing system $\left(X_{7}\right)$

Tingkat kesulitan untuk memenuhi persyaratan mengikuti program billing system pupuk bersubsidi diukur dengan mengamati sulit atau tidaknya responden memenuhi persyaratan yang ada sampai pupuk subsidi dapat ditebus oleh petani. Hasil penelitian menunjukkan bahwa mayoritas responden yaitu $80,65 \% \quad(75$ orang) berpendapat bahwa persyaratan mengikuti program billing system mudah untuk dipenuhi, $10,75 \% \quad(10$ orang) berpendapat sulit untuk dipenuhi, dan $8,60 \%$ ( 8 orang) berpendapat sangat sulit untuk dipenuhi.

\section{Dukungan pemerintah $\left(X_{8}\right)$}

Dukungan pemerintah diukur berdasarkan tingkat pendampingan dari pemerintah kepada petani di Kecamatan Candipuro terkait dengan program billing system pupuk bersubsidi, dilihat dari frekuensi pendampingan yang dilakukan oleh pihak pemerintah. Hasil penelitian menunjukkan bahwa frekuensi kegiatan pendampingan oleh PPL terhadap pelaksanaan program billing system pupuk bersubsidi di Kecamatan Candipuro termasuk dalam klasifikasi aktif, terdapat 52 responden $(55,91 \%)$ berpendapat frekuensi pendampingan PPL dirasakan aktif, 32 responden $(34,41 \%)$ berpendapat sangat aktif, dan 9 responden $(9,68 \%)$ berpendapat frekuensi pendampingan PPL rendah.

Kesesuaian harga pupuk subsidi menurut petani untuk menebus pupuk subsidi $\left(X_{9}\right)$

Kesesuaian harga pupuk subsidi menurut petani untuk menebus pupuk bersubsidi dikategorikan berdasarkan 2 (dua) hal yaitu, kesesuaian harga pupuk di kios pengecer dengan Harga Eceran Tertinggi (HET) dan perbandingan harga sebelum dan setelah ada program billing system pupuk bersubsidi di Kecamatan Candipuro. Hasil penelitian menunjukkan bahwa kesesuaian harga pupuk di kios pengecer dengan harga eceran tertinggi di Kecamatan Candipuro sangat tinggi yaitu sebesar 91,39\% atau sebanyak 86 responden berpendapat bahwa harga pupuk di Kecamatan Candipuro sudah sesuai dengan HET yang ditetapkan oleh Kementerian Pertanian. Perbandingan harga 
pupuk sebelum dan setelah dilaksanakan program billing system adalah 72 responden $(77,43 \%)$ berpendapat bahwa harga pupuk bersubsidi yang ada di kios pengecer setelah adanya program billing system lebih sesuai dengan HET. Hal ini disebabkan stok pupuk bersubsidi di kios yang selalu ada.

\section{Respon anggota kelompok tani terhadap program billing system}

Respon petani terhadap program billing system pupuk bersubsidi di Kecamatan Candipuro menjadi faktor utama keberlanjutan program ini pada tahun yang akan datang. Respon yang terbentuk dalam diri petani akan mempengaruhi cara pandangnya terhadap manfaat dan pelaksanaan program billing system pupuk bersubsidi. Indikator respon adalah keinginan untuk bertindak/ berpartisipasi aktif, membacakan/ mendengarkan, melihat, menimbulkan/ membangkitkan perasaan, dan mengamati (Sardiman, 1992; Nurmayasari et al. 2020; \& Viantimala et al. 2020).

Hasil penelitian memberikan gambaran bahwa respon petani terhadap program billing system dibagi kedalam tiga kategori yaitu cukup baik pada interval 18,120 - 23,440 sebanyak 13 responden atau $13,97 \%$, baik pada interval 23,441 28,759 sebanyak 54 responden atau $58,06 \%$, dan sangat baik pada interval 28,760-34,079 sebanyak 26 responden atau $27,95 \%$.

Respon petani terhadap suatu program erat kaitannya dengan kepuasan terhadap program tersebut (Hasanuddin et al. 2019). Apabila penyelenggaraan penyuluhan atau suatu program dilaksanakan secara benar, kontinyu, dan konsisten, maka tingkat kepuasan petani juga akan tinggi yang berdampak pada peningkatan kualitas hidup petani. Temuan penelitian selaras dengan Sukmayanto et al. (2019) yang menyatakan bahwa persepsi petani terhadap program billing system dilihat dari tujuan dan manfaat program dalam dikategorikan baik. Namun respon dan persepsi petani terhadap program billing system dari pelaksanaan program masih dalam kategori kurang baik. Oleh karen itu perlunya perbaikan dalam pelaksanakan program billing system di lapangan.

\section{Efektifitas program billing system}

Efektivitas pelaksanaan program billing system adalah tercapainya tujuan yang sesuai dengan tujuan dan sasaran yang direncanakan. Keberhasilan program penyaluran pupuk bersubsidi dikatakan berhasil jika pupuk tersebut memenuhi azas 6 (enam) tepat dan dikatakan tidak berhasil jika pupuk tersebut tidak memenuhi azas 6 (enam) tepat yaitu: jumlah, jenis, harga, tempat, waktu, dan mutu sesuai dengan Peraturan Gubernur Lampung Nomor 99 Tahun 2016.

Dari hasil olah data di lapangan menggunakan metode successive interval (MSI) maka di peroleh nilai kurang efektif pada interval 15,014-19,204 sebanyak 8 responden $(8,60 \%)$, cukup efektif pada interval 19,204-23,394 sebanyak 33 responden $(35,48 \%)$, dan efektif pada interval 23,394-27,585 sebanyak 52 responden $(55,91 \%)$. Hasil penelitian menunjukkan bahwa program billing system pupuk bersubsidi memiliki efektivitas yang tinggi. Efektivitas program yang tinggi yaitu sejauh mana program billing system pupuk bersubsidi dapat tepat sasaran sesuai dengan sasaran yang sudah ditetapkan sebelumnya. Sasaran dari program billing system pupuk bersubsidi adalah petani padi yang memperoleh pupuk bersubsidi.

\section{Pengujian Hipotesis}

Hubungan antara variabel X (faktorfaktor yang berhubungan dengan respon petani) dengan variabel $Y$ (respon anggota kelompok tani terhadap program billing system) dianalisis dengan menggunakan uji korelasi rank Spearman dengan bantuan SPSS 25. Hasil pengujian statistik faktorfaktor yang berhubungan dengan respon petani dan respon anggota kelompok tani terhadap program billing system pupuk bersubsidi dapat dilihat pada Tabel 2 . 
Tabel 2.

Hasil analisis faktor-faktor yang berhubungan dengan respon anggota kelompok tani terhadap program billing system pupuk bersubsidi

\begin{tabular}{clcccc}
\hline No & \multicolumn{1}{c}{ Variabel X } & Variabel Y & $\mathrm{r}_{\mathrm{s}}$ & Sig. & $\mathrm{A}$ \\
\hline 1 & Pendidikan formal & $\begin{array}{c}\text { Respon anggota } \\
\text { kelompok tani }\end{array}$ & $-0,014$ & 0,893 & 0,05 \\
2 & Lama mengikuti program & $-0,095$ & 0,365 & 0,05 \\
& billing & $\begin{array}{c}\text { terhadap program } \\
\text { billing system }\end{array}$ & $-0,093$ & 0,373 & 0,05 \\
3 & Luas usahatani & & 0,060 & 0,565 & 0,05 \\
4 & Status kepemilikan lahan & $-0,104$ & 0,322 & 0,05 \\
5 & Pendidikan non formal & 0,463 & 0,000 & 0,05 \\
6 & Tingkat pengetahuan & 0,256 & 0,013 & 0,05 \\
7 & Persyaratan & 0,516 & 0,000 & 0,05 \\
8 & Dukungan pemerintah & & 0,386 & 0,000 & 0,05 \\
9 & Kepemilikan modal & & & & \\
\hline
\end{tabular}

Sumber: Analisis data primer, 2019

Berdasarkan Tabel 2 dapat diketahui bahwa tingkat pendidikan formal, lama mengikuti program billing system pupuk bersubsidi, luas usahatani, status kepemilikan lahan, dan pendidikan non formal tidak berhubungan dengan respon petani terhadap program billing system pupuk bersubsidi. Sedangkan tingkat pengetahuan, persyaratan, dukungan pemerintah dan kesesuaian harga pupuk subsidi berhubungan dengan respon petani terhadap program billing system pupuk bersubsidi.

\section{SIMPULAN}

Berdasarkan hasil penelitian, respon petani terhadap program billing system pupuk bersubsidi adalah baik. Respon yang baik akan menimbulkan rasa nyaman dan memberi kemudahan dalam menerapkan suatu inovasi. Adanya kemampuan dan keterampilan serta keahlian dalam menjalankan teknologi pertanian akan mempengaruhi pelaksanaan program sesuai jadwal dan tepat waktu sehingga akan membantu untuk mendapatkan hasil yang baik sesuai dengan perencanaan. Hasil uji dan analisis terhadap variabel-variabel yang diduga, bahwa tingkat pengetahuan (X6), persyaratan peserta program (X7), dukungan pemerintah (X8), dan kesesuaian harga pupuk subsisi di tingkat petani (X9) mempunyai hubungan yang nyata terhadap peningkatan respon petani terahadap program billing system pupuk bersubsidi.

\section{DAFTAR PUSTAKA}

Adriyani, F.A. (2019). Pemanfaatan Cyber Extension sebagai Media Diseminasi Inovasi Pertanian oleh Penyuluh Pertanian di Provinsi Lampung. Suluh Pembangunan : Journal of Extension and Development. 1(1): 1-7.

Direktorat Jenderal Prasarana dan Sarana Pertanian Kementerian Pertanian RI. (2018). Petunjuk Pelaksanaan Penyediaan dan Penyaluran Pupuk Bersubsidi Tahun Anggaran 2018. Jakarta.

Hadi, P.U., D.K. Swastika, F.B.M. Dabukke, N.K. Agustin, M. Siregar, D. Hidayat, dan M. Maulana. (2007). Analisis Penawaran dan Permintaan Pupuk di Indonesia 2007 - 2012. Laporan Hasil Penelitian. Pusat Analisis Sosial Ekonomi dan Kebijakan Pertanian. Bogor.

Hasanuddin, T., Viantimala, B., dan Fitriyani, A. (2019). Kinerja Penyuluh Pertanian Lapangan, Kepuasan Petani, dan Produktivitas Usahatani Jagung di Kecamatan 
Natar, Kabupaten Lampung Selatan. Suluh Pembangunan : Journal of Extension and Development. 1(2): 134-141.

Listiana, I., Hudoyo, A., Prayitno, R.T., Mutolib, A., Yanfika, H. and Rahmat, A. (2020). Adoption Level of Environmentally Friendly Paddy Cultivated Innovation in Pringsewu District, Lampung Province, Indonesia. IOP Conf. Series: Journal of Physics: Conf. Series 1467 (2020) 012025. doi:10.1088/17426596/1467/1/012025.

Mantra. (2004). Filsafat Penelitian dan Metode Penelitian Sosial. Pustaka Pelajar. Yogyakarta.

Nurmayasari, I., Viantimala, B., Gultom, D.T., Yanfika, H. dan Mutolib, A. (2020). Partisipasi dan Kepuasan Petani Terhadap Kinerja Penyuluh Pertanian di Kecamatan Palas Kabupaten Lampung Selatan. MIMBAR AGRIBISNIS: Jurnal Pemikiran Masyarakat Ilmiah Berwawasan Agribisnis, 6(1): 448459.

Pudji, P.H. dan Sriningsih, E. (2003). Farmers' Response to The Program of Increasing the Production and Income of Rice Farming (A Case Study of the Subdistrict of Sokaraja, Banyumas Regency). Jurnal Pembangunan Pedesaan. Vol. III No. 1. Hal: $31-$ 38.
Riduwan. 2010. Skala Pengukuran Variabel-variabel Penelitian. Alfabeta. Bandung.

Sardiman, A.M. (1992). Interaksi dan Motivasi Belajar Mengajar, Jakarta: Rajawali Pers

Siegel, S. (1997). Statistik Non Parametrik Untuk Ilmu Sosial. Jakarta: PT. Gramedia Pustaka Utama.

Sukana, E., dan Notohadiprawiro, T. (2006). Peranan Pupuk dalam Pembangunan Pertanian. Repro: Ilmu Tanah Gadjah Mada. Hal: 1 - 23.

Sukmayanto, M., Alviana, E.D., Mutolib, A. (2019). Persepsi Petani Padi Terhadap Program Billing Sistem Di Kecamatan Metro Barat Kota Metro. MIMBAR AGRIBISNIS Jurnal Pemikiran Masyarakat Ilmiah Berwawasan Agribisnis, 5(1): 114123.

Viantimala, B., Yanfika, H., Mutolib, A., Listiana, L. dan Effendi, I. (2020). Kinerja Penyuluh dan Partisipasi Petani Dalam Kegiatan Penyuluhan Pertanian Di Kecamatan Kotagajah Kabupaten Lampung Tengah. Journal of Food System and Agribusiness. 4 (1): 9-16.

Wahyuni, S. (2019). Hubungan Karakteristik Inovasi dan Pola Komunikasi Terhadap Keberlanjutan Penerapan Teknologi Padi Salibu di Kabupaten Tanah Datar. Suluh Pembangunan : Journal of Extension and Development. 1 (2): 72-80. 